\title{
Relational autonomy: Kinship and daughters-in- law negotiating affinity with their mothers-in-law
}

Roderick Galam

Freie Universität Berlin

Research on mother- and daughter-in-law relationships has primarily focused on the conflict between the two. This article highlights the empowering potential of daughters-in-law of this problematic relationship by examining the struggle of Filipino seafarers’ wives to exercise agency and achieve autonomy in the context of living with their mothers-in-law. Drawing on in-depth semi-structured interviews, it analyses the women’s project for autonomy within kinship, that is, an autonomy deeply embedded in intersubjective relations through the conceptualisation of kinship as 'cultures of relatedness', which explicitly attends to the negative aspects of kinship. Three dimensions of their experiences are discussed: breaking their silence/talking back; becoming their husband's designated recipient of their remittances; and having their own house. Their experiences demonstrate the importance of retaining normativity in the conceptualisation of kinship as relatedness.

key words autonomy $\bullet$ mother-/daughter-in-law relationship $\bullet$ kinship $\bullet$ relatedness $\bullet$ affinity

• house • voice • male emigration • Ilocos, Philippines

\section{Introduction}

Being a wife is not just a status one assumes with the act of contracting marriage. Aside from bringing with it responsibilities and obligations, it also involves becoming part of a new web of relationships. These new affinal relations need careful negotiation. Although in-law 
relationships with the wife's father (Nydegger, 1986) and siblings of either spouse (Silverstein, 1990) have also been characterised as problematic, it is the relationship between daughter- and mother-in-law that is traditionally seen as conflict-filled (Wolf, 1972; Kandiyoti, 1988; Vlahoutsikou, 1997; Brown, 2004). Kandiyoti (1988: 279) describes as one of ‘deprivation and hardship’ the experiences of a new bride in a patriarchally extended family in North Africa, the Muslim Middle East (as well as Turkey, Pakistan and Iran), South Asia (India) and East Asia (China). Her subservience and submission to the authority of her mother-in-law will end when she herself becomes a mother-in-law who will impose the same asymmetrical power relation that had de ned her life as a wife. Brown (2004), who refers to a 'mother-in-law belt' extending from the Mediterranean to the Pacific, provides the following ideal-typical description of the relationship between the two women: 'At marriage the wife enters into a life of servitude and is expected to be obedient, submissive and stoic in the face of gratuitous mistreatment, both psychological and physical, until she becomes a mother-inlaw herself' (Brown, 2004: 168).

Although male emigration may have empowering consequences on women who stay behind, traditional gender ideology remains resilient. Bever (2002) notes in her Yucatan study that both men and women defended traditional gender ideology despite the changes brought about by the migration of husbands. De Haas and van Rooij (2010) note in their Moroccan study that the women did not see their experience of changes to their gender roles and responsibilities as emancipatory. Their taking over of their husbands' tasks was by default rather than sought by the women who were not prepared for or did not want the potential backlash from their society that was not ready for, and indeed may even be hostile towards, their new status (see also Salgado de Snyder 1993). Such hostility, expressed through social criticism and scandal mongering, could 'endanger their respectability and, hence, their social security’ which ‘can be disastrous in times of economic hardship’ (de Haas and van Rooij, 
2010: 59). Kandiyoti (1988) has referred to the negotiation that women do to secure or preserve their positions and wellbeing within existing patriarchal arrangements as 'bargaining with patriarchy'.

In classic patriarchy that Kandiyoti (1988) examines, this entails women in patriarchally extended families internalising patriarchal ideology as a strategy for achieving security in old age. Because such security is guaranteed through their sons, mothers-in-law work hard to ensure that their sons' primary allegiance is to them, and in making their sons' love for their wives secondary (Kandiyoti, 1988). In this account, the conflictual relationship that pits the two women in competition to secure their position obtains in a system of relations and values in which they are subordinated. While they manoeuvre for individual power within the family, they entrench and perpetuate the system of gender relations that valorise male privilege and that keep the women dependent on men (Shih and Pyke, 2009).

The seafarers' wives' project for autonomy provides a case that offers an account of how daughters-in-law, who reside virilocally, come to exercise authority, an account that differs from that provided, for example, in Kandiyoti (1988). The account provided here of how the wives become autonomous yet remain relational relies on a non- deterministic conception of the relationship between mothers- and daughters-in-law; that is, they are not characters whose actions have been predetermined by patrilineal ideology (Collier, 1974: 92-4; see also Shih and Pyke, 2010).This article highlights the empowering potential for daughters-in-law of the negotiation of the unequal relationship between daughters-and mothers-in-law, which appears not to have been systematically examined as studies have primarily focused on how the conflict between the two women has served as a barrier to female solidarity (Vlahoutsikou, 1997). I frame my examination of the autonomy project of daughters-in-law within the quotidian and material and affective practices of living together in order to explicate the 
dynamics of gender, generational hierarchy, family life and kinship relations that inform the autonomy and agency that daughters-in-law achieve.

This article conceptualises three major aspects that mark the process, indeed the project, of becoming autonomous. First, for some of the wives, autonomy begins with breaking their silence/talking back in the face of mistreatment from their mothers-in-law, and in the context of a strong cultural injunction to respect one's in-laws. The second looks into how this autonomy is linked to their becoming their husband's recipient of his remittances, a dynamic shaped by how the Philippine state has regulated the remittances of Filipino seafarers. The last examines how the women's autonomy is linked to having their own house. Indeed, finding a voice and becoming the designated recipient of their husband's remittances might be said to find their concretisation in having a house of their own. To that extent, it is the logical extension of finding a voice, of a voice finding its own dwelling and abode. By examining through the lens of kinship as relatedness how the women's autonomy project is embedded in intersubjective, particularly affine, relations, the article argues for retaining normativity as an integral part of the conceptualisation of kinship as relatedness (Miller, 2007).

\section{Labour migration, seafaring and kinship}

Kinship and labour migration are two important factors that have shaped the lives of the women. Their location and experiences within their husband's family were profoundly shaped by how Filipino kinship is established. It is bilaterally extended, that is, kinship is reckoned from both the mother and father's sides following both vertical (for example, grandparents) and horizontal (for example, cousins) structures of accounting relatives. This system of reckoning blood relations is also followed in establishing affinal relations, which are extended to the entire kin group of the spouse: 'the husband's and the wife's uncles, aunts 
and grandparents are agabalayan [in-laws] to each other ... the agabalayan relation has the weight of real kinship’ (Jocano, 1982: 41).Thus, when wives moved into their husband’s family's house, they negotiated the structural and cultural implications of these relationships on their lives and behaviour, particularly so if their husband was surrounded by neighbours who were his relatives. Although data from this study show a preponderance for virilocal residence (31 women out of 46 participants moved into their husband's house), in Philippine kinship there is no preference for either virilocal or uxorilocal residence (Go, 1993).

Consequently, the rigid and hierarchical relations that characterise the mother-inlaw/daughter- in-law relationship within patriarchally extended families (Kandiyoti, 1988) do not have the force of an unavoidable social law in Filipino society since a new couple can choose to live with the woman's natal family.

In the Ilocos Region, where the field research from which this article derives was conducted, a nuclear household is considered the basic socioeconomic unit, and couples are expected to establish their own household after marriage, although this may be delayed until after the birth of the couple's first child (Nydegger and Nydegger, 1966). The composition of Ilocano households is flexible such that it is very common to have other consanguines and affines as part of the household (Jocano, 1982; Nagasaka, 1999). Due mainly to economic difficulties, couples are not able to establish neolocal residence soon after their first child is born, and so continue to live with their families until they have built their own house, which could take years. Labour migration, specifically seafaring, has been the principal way for the research participants' husbands to realise this goal.

Seafarers' work - characterised by insecurity and long periods of unemployment in between contracts - has shaped the temporality and spatiality of the lives of the women. Their husbands' employment onboard ships on the international fleet meant that not only did the 
women live with their mothers-in-law, but also, even more critically, that they lived with her without their husband for long periods of time. The women therefore had to deal with the difficulties of living with in-laws on their own and without the help of the person they considered their ally. Their husband's period of unemployment between contracts, which could last for several months, has significant financial implications on their family’s lives and capacity to save enough money to build their own house.

As detailed below, while living with their husband's family and in proximity to many of his relatives, the wives were compelled by a strong socio-cultural norm to respect their in-laws. And as the one who moved into the house, they, particularly those who were not in paid employment, felt an expectation to serve their husband's family by, for example, being the first to get up in the morning to cook and clean. Most of the wives reported that their residential arrangement had their movement monitored and their freedom curtailed. Some suffered mistreatment from their mothers-in-law whose actions included gossiping about them, verbal abuse and attempts to ruin their marriage.

Analysing how this intimacy of conflict constituted the agency and autonomy of the wives not only shows how the wives suffered in unequal relations of power, but also illuminates the ways that this conflict can be empowering as it provided the impetus for them to assert themselves. Framing it within kinship, particularly affinal relationships, will help clarify 'the material and emotional ways that individuals are intimately involved with each other and the negotiated aspects of relatedness' (van Vleet, 2002: 568). It will also reveal the given principles (Miller, 2007) that underpin this relationship and that constitute its negotiation, particularly the asymmetries (Vera-Sanso,1 999; Vlahoutsikou, 1997; van Vleet, 2002) that define and undergird it. 
Janet Carsten has noted that anthropological studies of kinship that have looked at it as structure have concentrated on its 'positive and harmonious aspects', neglecting the fact that it is also about 'disconnection and disjunction' (2000: 24) as well as 'differentiation, hierarchy, exclusion, and abuse' (2013:247). Carsten (2000:1) writes that although the social, material and affective connections of people to others 'can be described in genealogical terms', there are other ways of accounting for how these connections are established and maintained. She conceptualises kinship as cultures of relatedness (Carsten 2000, 2007, 2013). 'Cultures of relatedness' looks at kinship as lived experience rather than as structure or system of classification (Carsten, 2007: 3; see also Finch and Mason, 2000: chapter 7). Kinship, as relatedness, relies for its construction on everyday practices - 'small, seemingly trivial, or taken-for-granted acts like sharing a meal, giving a dish of cooked food to a neighbour, dropping in to a nearby house for a quiet chat' (Carsten, 2000: 18). Looking at kinship as practices of relatedness highlights kinship’s processuality (Carsten, 2000; Aguilar, 2009a). This is particularly salient for the Philippines, a country with over 10 million comprising around $10 \%$ of its population - of its citizens living and working overseas.

The separation of family members due to international migration has significantly shaped the ways and practices that those left behind and those away sustain relationships. The performance of obligations and provision of care have to be adjusted with corresponding consequences on family and kin ties and relationships (Parrenas, 2005; Aguilar, 2009a). The separation also presents new challenges for members to face, exacerbates existing problems in marital or affinal relationships (see Pingol, 2001), and provides or intensifies the conditions for problems in relationships to become more visible, as the case of seafarers' wives in this article will show. This negative side of kinship can be attended to by conceptualising kinship as relatedness as it pays attention to the practices and actions, both 
positive and negative, that people do (Carsten 2000; Aguilar, 2009a) to shape, sustain, assert, or even ruin, relationships.

The conceptualisation of kinship as process and practices, however, sets aside, as Miller (2007) has noted, aspects of relationships and how they are negotiated that remain dependent on norms, principles and codes of behaviour. Studies of Philippine kinship, particularly in the context of transnational migration that have used the prism of relatedness (Aguilar, 2009a,

2009b), have not explicitly incorporated how socio- cultural norms and principles continue to shape relationships and their negotiation (Miller, 2007), despite them implicitly underpinning the analyses offered. Aguilar, the main proponent of looking at Filipino kinship as ties of relatedness, however, implicitly acknowledges the continuing salience of these norms in his more recent work on siblingship (Aguilar, 2013). Nagasaka’s study of the processuality, flexibility and ambiguity of kinship in the context of the experiences of children from an Ilocos village growing up in a transnational family shows that 'normative discourses on family, parent-child and mother-child relationships’ remain important (Nagasaka, 2015: 22). As the experiences of the seafarers' wives will show, kinship retains elements of expectations of how one should behave towards in-laws such that their relationship with their mothers-inlaw and the practices that informed it were shaped by normative understandings of daughtersin-law’s 'proper behaviour' towards their mothers-in-law.

\section{Methodology}

The present article derives from a study that examined the spatiotemporality of the subjectivity, agency and identity of left-behind Filipino seafarers’ wives. I conducted 40 indepth semi-structured interviews with seafarers' wives in 2010 and an additional 10 interviews between December 2011 and January 2012 in the town of San Gabriel, in Ilocos Norte, northwest Philippines. Research participants were selected purposively to include a 
relevant range of socioeconomic, family, employment and residential experiences using the following parameters: wives in full-time employment; wives not in employment; wives with dependent children; wives with adult children; wives with no children; wives who live with their in-laws; wives whose husbands have risen to the rank of chief engineer or captain; wives whose husbands have retired; and wives whose husbands have stopped working because of illness. These parameters were taken to vitally shape the women's lives and how they experienced their husband's migration. The youngest interviewee was 21, the oldest, 53. Only eight of the women were in full-time, paid employment, with six of them in the public sector (teacher, social worker). Of the 32 who were not in paid employment, 19 were engaged in some form of income-generating or economic activity (farming, raising livestock, buying and selling of food items, and owning a tianggi [small store]). Only four of the 46 interviewees were not mothers. Between October 2013 and June 2014, I re-interviewed 10 of the 40 interviewees in my 2010 fieldwork to inquire about changes in their life situation, and interviewed one additional wife who used to live with her in-laws. This article therefore draws on interviews with 10 wives who used to live with their in-laws but who now live in a separate house, and with 21wives who, at the time of the interview, lived with their mothersin-law. Insights are also drawn from interviews with 15 women who were living with their natal families at the time of the interview, and women who used to live with their natal families but who now live in their own houses.

This discussion of relational autonomy and its negotiation within a ne relations draws exclusively from the perspective of daughters-in-law, and especially those who lived with their mothers-in-law. It does not include the perspectives of husbands and mothers-in-law. My informal conversations with 10 husbands revealed that their wife's relationship with their own mother was not a subject they were willing to discuss, excusing themselves by the fact that they were away most of the time and 'did not really know what was going on'. I did not 
talk to the mothers-in-law for ethical reasons. Interviewing both of them had the potential to further strain the relationship between the two women. It would have put the daughters-inlaw in a di cult position. It was possible that they would think that what they shared would feed into my questions to their mothers-in-law. Furthermore, the mothers-in-law would have probably also thought that my questions were based on what their daughters-in-law had shared with me. Clearly, the fact that the women lived in the same house made interviewing both of them extremely difficult and ethically problematic. Indeed, asking the women about their relationship with their mothers-in-law made them uncomfortable because we were in their in-laws' house. The interview took into account the presence in the house of the mothers-in-law who, despite not being within hearing distance, made the women feel uncomfortable talking about their relationship with them. Several times I was asked to assure the participants that what they were going to say would remain confidential, and they proceeded to talk in a lowered voice. Truly, place of residence and the 'haunting' presence of their mothers-in-law had significant consequences on the women’s freedom of expression.

\section{Breaking their silence/talking back}

Every one of the wives spoke of a cultural expectation to show respect to their parents-inlaw. Such expectation originates in the inculcation among young children of respect for parents, other older relatives and generally any older person. Article 357 of the Civil Code of the Philippines, arguably a codification of Filipino social and cultural values, explicitly instructs children to obey and honour their parents, and to respect their grandparents and old relatives (Pangalangan, 1995: 21). In fact, many of the wives who lived with their in-laws stated that if they were taught since they were young to respect their parents and other elders, even more respect is to be shown to their in-laws. They may disrespect their own parents, but never their in-laws. This was cogently expressed by Jessica, 33 years old, who used to live 
with her in-laws but who now lives in a house that shares a wall with her in-laws: 'Your inlaws mark the limits of your propriety and respect. You can talk back to your parents but not your in-laws. If you do not show respect to your in-laws, then you really are shameless.'1 Jessica's statement reveals the close affinity between respect and shame in Ilocos society. To show respect is to exercise bain (shame), that is, for one's actions to be guided by a deep sense of propriety (see also Torres-Mejia, 2000: 141). When the women married, they (and their husbands) were fully aware of this cultural injunction, and would have always treaded carefully not to disrespect or o end their parents-in-law. This was particularly true of wives who went on to live with their husband's family and came under the close watch of their mother-in-law. Respect, and its inculcation, function as a disciplinary practice by which children and adults learn to police their own selves. It acts as a cultural and social force that makes people watch how they behave, what they say and the tone in which they say it. It is a way by which parents and elders could exercise authority and perpetuate hierarchy. This cultural premium placed on respect compelled the women to suffer in silence; indeed, it might be argued to be tacitly founded on a culture of silence. Many of the wives who lived and were living with their mothers-in-law endured mistreatment and initially suffered in silence. Gina and Marissa illustrate this.

\section{Gina: 'bad words'}

I just kept quiet. When it became too much, that's when I talked back. Super. I really had a row with her [mother-in-law]. I couldn't stop what came out of my mouth. They were really bad words, because I was just in my room, not saying anything. She even dragged in my family, saying things about my family. I have had too much, so I just, you know, even if my husband was there, it was good my husband was around. He tried to cover my mouth, 'That's 
enough!', he said. Then he turned to her, 'It's your fault mama, she [Gina] wasn’t even saying a single word yet you kept on and on and on there,' he said.

Gina relates that living with her mother-in-law included suffering verbal abuse, constant monitoring of her activities, invading her own life (her mother-in-law would shout to tell her to take her birth control pills and not to have too many children, which she found infantilising, 'as though I did not have a mind of my own'). She was, in her own words, being controlled.

Marissa: 'I became shameless and disrespectful'

But I learned to talk back. [...] Then, I did not know how to talk back, I did not know how to fight back. But when I realised ... why should I allow it, why should I be oppressed? Why do I not fight for myself when in fact I can? That's how I learned. You know, my behaviour now, like I have become shameless. [...] I really don’t want to be treated lowly ... what I want is when something is said to me, I confront the person.[...] My mother-in-law, when she says something like that, I really talk back. Before, I was never capable of talking back to her. But because they themselves taught me. She tells me, 'You are shameless'. 'It's you who taught me', I tell her. 'When I moved in to this house’, I say, ‘did you hear me say anything? No. Did you hear me talk back? No.'[...] 'You are shameless and disrespectful.' 'I am shameless and disrespectful because of you. I learned to talk back because of you. If I don’t fight for myself, you mean to say you'll just trample on me, you'll just step on me?’ I said.

The sheer need to defend herself pushed Marissa to speak out. Yet we can also see the force of the cultural injunction to respect one's in-laws in her characterisation of her becoming assertive as turning into a disrespectful woman. 
Talking back was a critical first step in the assertion and development of identity and agency, and a crucial beginning in the women's exercise of power and in addressing the asymmetries of power relations in which they frequently found themselves. Gina's breaking her silence was a point of no return. It was this experience that made her want to move out of her mother-in-law's house where she felt she could not breathe (para kang hindi makahinga). Marissa's talking back was a de ant and belligerent act, shocking her mother-in-law by the force of her assertiveness and new-found confidence. Her mother-in-law could only say Marissa was natangsit (arrogant and disrespectful), thereby exposing an expectation for her to be meek. Both women demonstrate that there is a limit to their being respectful. From their talking back emerged a sound, the sound of the women's voice breaking the prison-house of respect and the splintering of an old self giving way to a new one. Experienced by the wives as liberating, talking back was a de ant act precisely because it meant becoming freed from an ideological and cultural doctrine that valued silence - understood as obedience, submission and subservience.

\section{Becoming the allottee}

After marriage, women, specifically those who lived with their husband's family, did not automatically become the recipient (allottee) of their husband's remittances (allotment). The Philippine state, through Executive Order Number 857 issued by President Marcos in December 1982, made it mandatory for overseas contract workers to remit regularly 50 to $80 \%$ of their income through the Philippine banking system (Aguilar, 2003). Seafarers, however, had no choice since their salaries were paid by manning agencies based in Manila. This regulation compelled unmarried seamen to designate a beneficiary who, most often than not, was their mother. Both state and familial obligations ensured that the mother became the 'legal' recipient of her son's allotment. Women who moved into their husband's family had 
to live with this arrangement in place. Six women who lived or used to live with their mothers- in-law waited for at least two years before they became their husband's beneficiary. This, however, did not stop their husband's financial support for their mother or natal family, which the wives perfectly understood.

Getting their husband to have them replace their mother-in-law as the allottee was, however, fraught with conflict. The women asserted that as wives, they should be the beneficiary, and that this was an important component of their position within their own family and status as wives. As Gina said:

Because in [my husband's] first and second contracts, it was they [who received the allotment]. He [her husband] himself decided to transfer it to me. But then still what my mother-in-law wanted to happen is I hold the bankbook but the account is in her name and her son. I hold the bankbook! [...] Seriously, who would agree to that? What woman will agree to such an arrangement?

The allotment was therefore as much about money as about what it symbolised. Aida, who did not live at all with her mother-in-law, shared that her mother-in-law, who has four other children working overseas, still asked for money from her husband. She recalled what her mother-in-law once said to other people and that reached her - that her son's affections were no longer hers. Aida’s mother-in-law appreciated the money her son gave her, not only on account of her financial need, but also as proof that she still had a place in her son's universe of affection. Most mothers, however, did not have other children to depend on, and hence might have viewed their daughters-in-law as threatening their economic wellbeing.

Many Filipinos who take maritime-related courses come from rural and poor backgrounds (Amante, 2005). They see working as seafarers in the global maritime industry as a way to 
obtain a better life. If parents struggled through great financial difficulty to send them to school, it is with both a sense of duty and gladness that these seafarers support them once they start earning. Many of these seamen's mothers would have been unemployed and have only them to rely on, especially in their old age. We can at least understand, however partially, why mothers would wish to remain as their son's beneficiary. It is also helpful to understand some of the husbands' initial hesitation to change their allottee from their mother to their wife within the context of a debt of gratitude (utang a naimbag a nakem), which informs the sense of obligation these seafarers have for their parents, siblings and members of their extended family. A moral character undergirds the sons' fulfilment of their kin obligations (see also Finch, 1989). A seaman refusing to extend financial help to his family would be seen as neglecting or abandoning them. The seamen's wives knew this well, and they themselves helped their families. The issue is that they were at the mercy of their mothers-in-law. Wives who lived with their mothers-in-law who acted as conduit for their husband's monthly remittances recalled how very little freedom they had, even in the way they spent their money. Laura, for example, uses the word pinapakialaman (meddled with and dictated on) to describe her experience. Marissa shared how her mother-in-law constantly reminded her how to spend her son's money. When she finally became her husband's beneficiary, her mother-in-law manoeuvred to cause Marissa and her husband to separate. Even wives who did not live with their mothers-in-law suffered as a result of their becoming the allottee. Nancy, who lived just across the street from her in-laws, recalled how her relations with them (not just her mother-in-law) progressively soured and became unpleasant when she started receiving the allotment.

Becoming their husbands' beneficiary gave them a sense of control, one that obtained for them both symbolic and material purchase on power. This boosted their position in a house in which they felt under their mother-in-law's authority. Becoming the recipient of their 
husband's allotment peeled away one layer of the structures of power they had to negotiate. Their mother-in-law ceased to exist as the mediator through which their monthly financial support passed. It made it untenable for their mother-in-law to tell them how to spend their son's money. It confirms and affirms the primacy of the conjugal relationship over that of the parent-son bond (Vlahoutsikou, 1997). Becoming the allottee therefore restructured the ties that bound them, both hierarchical and affective ties that strengthened and reinforced spousal relationship. Mothers-in-law might have perceived this as marginalising them both affectively and materially. This demonstrates, as vanVleet (2002: 578) has noted, how the 'affective and economic relationship between a mother- and daughter-in-law is intertwined with the structural relationship and more general system of values that shapes the relationships between parents and children.' The restructuring of relationships between parents and children, specifically adult children no longer coming under the authority of parents, is established most clearly by the married couple having their own house.

\section{A house of their own}

The social and individual meaning and significance of a house has been widely examined, particularly in anthropology. Much of the literature has focused on how the house and its construction is the focal point of kin and social relations, validates and strengthens social and individual identities and statuses, and affirms filial obligations (Carsten, 1995; Carsten and Jones-Hughes, 1995; Grigolini, 2005; Aguilar, 2009a, 2009b).This section broadly shares this concern, but my strategy highlights the social significance of the house by underscoring how it matters to daughters-in-law who moved residence virilocally. For most of the women, living with their in-laws was generally unpleasant. Grace, who described what she felt like when her husband was coming home, effectively described her life with her mother-in-law: 
You are excited, it's like you will now have an ally. [...]You'll feel comfortable because he’s there, you can smile really beautifully. You will be able to laugh. But if he’s not around, nothing, you'll be very quiet. It's as though even your breathing is not free, like it’s really hard to breathe.

Grace's use of the word kakampi (ally) alludes to conflicts in the house. Living with her mother-in-law is like living with enemies. Her husband's return meant she could smile again, that she could breathe freely again. Women who lived with their in-laws saw having their own house as giving them the possibility and actuality for self-determination, the ability to control things in their families that otherwise would have been di cult to do had they continued living with others.

'You can control your expenditures better'

A number of women cited the strain put on their budgets by living with others. This was also true of women who lived with their own natal families. For women who lived with their inlaws and who already had the issue of allotment to contend with, expenses for food and utility bills added to the things they had to carefully manage. When women tightened their belts according to their financial situation, their mothers-in-law made negative remarks, which reached them through other people. This was what happened to Grace, and her motherin-law's gossiping about her 'not buying adequate food' motivated her to have separate cooking arrangements. Becoming a separate household was a first step towards having more control of how much the family spent. This mattered a lot to the women because it also meant that they could save more.

The time their husbands were unemployed between contracts loomed large in their horizon. Jessica’s mother-in-law’s remarks about her not buying enough food for everyone (which 
Jessica took as a veiled accusation of her not including his husband's natal family in her groceries) motivated her to put pressure on her husband to build a small house that shared a wall with her mother-in-law's house. Mothers-in-law who have ceased to be their son's allottee might be seen to use gossip to compel their daughter-in-law to share resources. Thus, gossip is used as a way of continuing to exert influence (Wert and Salovey, 2004) over spending or money that mothers-in-law used to have more power over. The gossiping indicates tensions (Wilson, 2012) in the relationship between the two women, and mothersin-law resort to it to maintain or gain access to material resources.

\section{'You can do as you please'}

Living with in-laws gave the women the feeling that they were monitored. As Grace said, 'it’s like someone is watching your every move, [...] like you are being monitored.' Living in a house that was not theirs limited the freedom they enjoyed. They said, for example, that if they did not feel like washing the dishes just yet, they could not put o doing it. They felt compelled to behave according to 'expectations' or to ones they imagined were expected of them. As one wife said, having her own house would enable her to do as she pleased. Another said having her own would enable her to breathe. The women saw having their own house as their means of having the freedom to do as they pleased. As Mildred said:

... if you had your own house, you could do what you want. If you lived in somebody else’s house, you are embarrassed to even rest. You can just be idle if it was your own house. You can sleep if and when you want.

Grace referred to how this freedom had liberating effects, not only on her movement, but also on her body: 'Nothing in you tenses.... Because it is yours, you can move freely. You can do what you want to do.' 
For women who lived or were living with their in-laws, all of the experiences discussed above contributed to their desire to have their own house. Earlier, I talked about women finding their own voice, a voice directed against their mother-in-law, and about how it was the beginning of a process of self-assertion. It might be argued that living in their own house was the beginning of these women's self-determination, when finally they were not dominated by their mothers-in-law. Women employed various ways to realise this. For example, Linda left her husband's family house where they had lived with her in-laws, and did so while her husband was at sea and before she told him of this decision. She had found living with her mother-in-law without her husband around simply unbearable. She vowed never to live again in San Gabriel unless in her own house. She had agreed to go back to her in-law’s house because her husband was on leave but, more importantly, her husband had agreed to build their own house.

Linda's action was de ant, but she still showed respect for social values, since leaving while her husband was away and without knowledge of this decision effectively absolved him of the conflict between her and her mother-in-law. Linda hence left open for him the role of restoring frayed relationships. When the husband came home, he had to fetch her and their daughter. Ill feelings that remained were temporarily set aside in this rite of restoration. Her mother-in-law could not refuse her because it meant refusing her own son. This rite of restoration, however, was only transitional, since Linda had, in fact, used her decision to leave to demand that her husband build a house she could make into her own home, albeit one that was going to be just a few steps away from her in-laws' house. Although the husband remained the agent for restoring things, she nevertheless positioned herself to reorder structures of authority and respect. At the time of the interview in 2010, Linda was waiting for the blueprint of the house for construction to commence. 
Although Linda did not exchange words with her mother-in-law, her actions spoke louder. There were a few women, however, like Grace, whose voice remained muted: 'of course, sometimes it really hurts, there's nothing I could do except cry.'

Grace, however, directed her voice to her husband, a voice insistent in its demand for autonomy. Linda summed up the women's desire to live in a house of their own:

... you never know what sin you are already committing. You think what you're doing is okay. To them it is not. If you're not feeling well, if you're living in someone else's house, you are forced to do your chores. If it was your own house, you can say, 'That can wait. I am going to just sit down, I have a headache.' You can always do so. You really have to be on your own. It is different when it is your own, you can really be independent. The house you see as a symbol of your independence.

Building one’s own house has, of course, financial implications. Money was not always available, so a house became a long-term project, finished over many years. It was a process adapted to the financial situation of the family, moving in sync with the family's life course. With children going to college or university, resources had to be prioritised, and so the building and completion of the house was done little by little, in modular fashion. As Luz said, their house evolved as a series of extensions, emerging from work done when there was money saved for it. Their house grew as their children grew up. For Grace, convincing her husband to build her even only a basic house was not easy. The availability of money was not the only issue in her husband's case. Her husband's indecision to build one for his own family had to do with kinship structure. As the youngest son, he will inherit the family house, and building one for his family therefore seemed to misuse money, which Grace herself understood. She was, however, desperate to move out of her mother-in-law's house. It did not 
matter to her that the house was only a basic structure and that it was unfinished. She would take charge of getting something done, little by little.

\section{Discussion and conclusion}

This article has examined the autonomy projects of Filipino seafarers' wives in the context of the 'intersubjective relations of kinship’ (Carsten, 2013: 249). It has provided an empirically grounded conceptualisation of the dynamic and texture of the women's relationship with their mothers-in-law in the context of the absence of their husbands due to labour migration. Male emigration and their co-residence with their mothers-in-law led the women to desire and indeed seek improvements in their agency as wives and daughters-in-law. This is a sense of agency that affirmed both their autonomy and their interdependence with others. It freed them from the controlling authority of their mothers-in-law and strengthened conjugal bonds. Admittedly, although such a project increased their agency within their own family (of procreation) and the wider web of affinal kinship, the ‘patriarchal bargain’ (Kandiyoti 1988) is that such agency obtains in the husband remaining the main, if not, sole, provider. Although this indicates their family's financial dependence on their husband, it also points to interdependence. The women's contribution to the maintenance and welfare of the family in the absence of their husband was different and no less significant. Indeed, the women, whether employed or not, pointed to the immense work they performed keeping the family intact in order to make their husband's labour migration a viable strategy of obtaining a better life.

For the women, this better life meant not only improving the family’s financial security, but also obtaining autonomy for themselves. Their autonomy project did not mean turning away from familial and kin obligations. Indeed, for the women, autonomy was fundamentally relational. This goes against how agency and autonomy have been conceptualised in the 
‘individualisation thesis’ that has become influential in social theory and sociological research. Beck and Beck-Gernsheim (2002: 22-3), influential proponents of this idea, have written that 'The choosing, deciding, shaping human being who aspires to be the author of his or her own life, the creator of an individual identity, is the central character of our time.' The individualisation thesis has been extended to the study of intimate relationships, but as Mason (2004: 163) has pointed out, the analysis is questionable in the face of research that has found how 'individual identities and life projects mesh with the connectivity of kinship and interpersonal relationships.'

Autonomy meant being able to exercise a sufficient degree of self-determination, the exercise of which would give them a position in which to view their social location and their participation in it in more positive terms. Oppression and maltreatment intensified their desire for it while giving it a new slant and nuance. Women who lived with their mothers-in-law and whose mothers-in-law received their husband's allotment felt the absence of this same freedom in how they spent their money. They were told by their mothers-in-law to spend it appropriately. Such meddling by mothers-in-law combined with other forms of mistreatment the women suffered in their hands taught them to talk back. Reared in a culture that puts a premium on respecting parents and elders, these women began the process of asserting their self and identity with their answering and fighting back. They were not merely redefining their relationships with their mothers-in-law, but also changing the terms of this relationship.

By answering back, that is, in facing their mothers-in-law, these oppressed daughters- in-law were questioning, that is, turning their back on, the cultural and social ideology that has taught them to suffer in silence. They began to demand and practice a more horizontal, rather than vertical, exchange of respect, a demand that ironically became possible for them to make only by becoming 'shameless' and 'disrespectful'. Their experiences intensified their desire 
for a house of their own, a space within which they could exercise freedom, for themselves and for their families. They linked their independence, freedom, autonomy, identity and agency to a house of their own. The house was the condition and space of possibility for them to have a life of their own. As Pauli (2008: 181) also noted of Mexican women married to spouses working in the US, a house of their own is 'an important expression of agency and creativity.'

What a house meant to the women varied depending on their location in kin relations. Women who lived with their natal families wanted a house of their own to become independent, but this desire was not engendered by oppression. Indeed, they built their own houses near their natal family's house that enabled them to be by their family's side in times when they or their natal family needed help. Like women who initially lived uxorilocally, those who lived virilocally also desired independence, which was vitally informed by their experiences of living with their mothers-in-law. Where wives lived with or near their husband's family and had good relations with them, owning a house may have meant independence, but not with the intensity with which it was desired by the women who lived with their mothers-in-law, who made their lives unbearable. They described living with their mothers-in-law as akin to extinguishing the life out of them, and saw living in their own house as life-giving. Many of the women said that having a house of their own would enable them to breathe, and to breathe freely. Living in their own house eased the tension between the two women. Indeed, Linda, who was waiting for the blueprint of her house in 2010 and who I re-interviewed in April 2014, reported improved relations with her mother-in-law as a result of living in her own house, an improvement also reported by those who built their own houses long ago. 
Having their own house did not mean that the women escaped their in-laws totally. Two of the wives who had di cult relationships with their respective mother-in- law were going to have their house built on a piece of land given to them by their husband's parents and within the family's compound. Their own house would give them self-determination but also locate them in the community of their husband's family and relatives, and in proximity to the person they wanted to stay away from. Kinship structure and the paucity of money, however, have made it more di cult for these women and their husbands to build elsewhere. The piece of land is their husband's birth right or inheritance; using it saves them money that could then be added to their budget for building their house.

The women's relationship with their mothers-in-law and the experiences it engendered would show that kinship is a 'negotiated experience’ (Miller, 2007; see alsoVera-Sanso, 1999) and ‘constituted in relational practices’ (Finch and Mason, 2000: 164). The relationship between the two women, however, was shaped by a cultural code to respect one’s in-laws. Also, the case of Linda, who fled her husband's house and who used this action to convince her husband of the necessity and urgency of having their own house, shows how the negotiation of affinity was shaped by what Schneider (1980: 26) calls ‘a pattern for behaviour' or 'a code of conduct'. Linda's fleeing triggered a series of actions, primarily done by her husband, to restore the peace between her and her mother-in-law. Linda's action and the 'rite of restoration' that followed relied on long-established principles, which underpinned not only Linda’s negotiation of affinity with her mother-in-law, but also her renegotiation of the terms of their relationship. Further, the case of Grace, whose husband, being the youngest son, will inherit the family house, indicated how her attainment of autonomy, which she inextricably bound up with having her own house, was strongly being shaped by established principles. Grace's having or not having her own house in turn shaped her relationship with her motherin-law and her experience of affine relations. This demonstrates how affinal kinship is shaped 
by the interaction between, on the one hand, cultural ideals and, on the other, the interests and goals of different family members and how they influence both their everyday existence and relationships (Shih and Pyke, 2009). Kinship is therefore relatedness shaped by what Miller (2007) calls ‘a set of normative categories' (536) or 'a given principle’ (537).

This article shows how these 'normative formal expectations' (Miller, 2007: 553) shaped and structured the wives’ relationship with their mothers-in-law and their negotiation of it. It provides empirical support to the importance of retaining normativity in the conceptualisation of kinship as relatedness (Miller, 2007).

The experiences of the women show the embeddedness of their autonomy projects in thick kin, especially affine, relations. The women's desire to have and live in their own house is an expression of the cultural ideal of achieving the status of no longer being and coming under the authority of their parents or parents-in-law. Such separation from parental or affinal authority, however, does not mean an abandonment of family obligations (see also Aguilar, 2013). Although their autonomy projects were forged in conflict and antagonism, they did not aspire to cut o ties from the people who made their lives difficult. Their life goals and meanings were de ned by and derived from their belonging to a family, both their own and their extended ones. Their selves are at once intersubjective and their autonomy relational.

\section{Note}

${ }^{1}$ All interview extracts are quoted in their English translation. All names used are pseudonyms.

\section{Acknowledgements}


I thank the reviewers for their comments that helped to improve this article, Carlos Piocos and especially Itaru Nagasaka for commenting on a draft, the women who participated in my research, and the Nippon Foundation for funding it.

\section{References}

Aguilar, F Jr, 2003, Global migrations, old forms of labor, and new transborder class relations, Southeast Asian Studies, 41, 2, 137-61

Aguilar, F Jr, 2009a, Maalwang buhay: Family, overseas migration, and cultures of relatedness in Barangay Paraiso, Quezon City: Ateneo de Manila University Press

Aguilar, F Jr, 2009b, Labour migration and ties of relatedness: diasporic houses and investments in memory in a rural Philippine village, Thesis Eleven, 98, 1, 88-114

Aguilar, F Jr, 2013, Brother’s keeper? siblingship, overseas migration, and centripetal ethnography in a Philippine village, Ethnography, 14, 3, 346-68

Amante, M, 2005, Philippine global seafarers: ethnicity and identity in ships with multinational crews, MINDAyawan Journal of Culture and Society, 2, 2, 1-23

Beck, U, Beck-Gernsheim, E, 2002, Individualisation: Institutionalised individualism and its social and political consequences, London: Sage

Bever, S, 2002, Migration and the transformation of gender roles and hierarchies in Yucatan, Urban Anthropology, 31, 2, 199-230

Brown, J, 2004,Transitions in the life-course of women, in C Ember and M Ember (eds) Encyclopedia of sex and gender, New York: Kluwer Academic-Plenum, 163-74 Carsten, J, 1995, Houses in Langkawi: stable structures or mobile homes, in J Carsten 
and S Hugh-Jones (eds) About the house: Levi-Strauss and beyond, Cambridge: Cambridge University Press, 105-28

Carsten, J, 2000, Introduction: cultures of relatedness, in J Carsten (ed) Cultures of relatedness: New approaches to the study of kinship, Cambridge: Cambridge University Press, $1-36$

Carsten, J, 2007, Introduction: ghosts of memory, in J Carsten (ed) Ghosts of memory: Essays on remembrance and relatedness, Oxford: Blackwell, 1-35 Carsten, J, 2013, What kinship does - and how, HAU: Journal of Ethnographic Theory, 3, 2, 245-51Carsten, J, Hugh-Jones, S, 1995, Introduction: about the house - LeviStrauss and beyond, in J Carsten and S Hugh-Jones (eds) About the house: Levi-Strauss and beyond, Cambridge: Cambridge University Press, 1-46 Collier, J, 1974, Women in politics, in M. Rosaldo and L. Lamphere (eds) Women, culture and society, Stanford: Stanford University Press, 89-96

de Haas, H, van Rooij, A, 2010, Migration as emancipation? The impact of internal and international migration on the position of women left behind in rural Morocco, Oxford Development Studies, 38, 1, 43-62Finch, J, 1989, Family obligations and social change, Cambridge: Polity Press

Finch, J, Mason, J, 2000, Passing on: Kinship and inheritance in England, London: Routledge

Go, S, 1993, The Filipino family in the eighties, Manila: DLSU Social Development Research Centre 
Grigolini, S, 2005, When houses provide more than shelter: analyzing the uses of remittances within their sociocultural context, in L Trager (ed) Migration and economy: Global and local dynamics, Lanham, MD: Altamira Press, 193-223

Jocano, F L, 1982, The Ilocanos: An ethnography of family and community life in the Ilocos Region, Quezon City: University of the Philippines Asian Centre

Kandiyoti, D, 1988, Bargaining with patriarchy, Gender and Society, 2, 3, 274-90 Mason, J, 2004, Personal narratives, relational selves: residential histories in the living

and telling, Sociological Review, 52, 2, 162-79

Miller, D, 2007,What is a relationship? Is kinship negotiated experience? Ethnos, 72,

\section{4, 535-54}

Nagasaka, I, 1999, Bringing up the children of migrants: continuity and change of Ilocano child fosterage, Asian Studies: Journal of Critical Perspectives on Asia, 35, 28-43 Nagasaka, I, 2015, Growing up in a transnational family: experiences of family separation and reuni cation of Filipino migrants’ children in Italy, in K Um and S Gaspar (eds) Southeast Asian migration: People on the move in search of work, marriage and refuge, Brighton: Sussex Academic Press, pp 8-39

Nydegger, C, 1986, Asymmetrical kin and the problematic son-in-law, in N Datan, A Greene and H Reese (eds) Life-span developmental psychology: Intergenerational relations, Hillsdale, NJ: Lawrence Erlbaum Associates, 99-123

Nydegger, W, Nydegger, C, 1966, Tarong: An Ilocos barrio in the Philippines, New York:

Wiley

Pangalangan, E, 1995, The family under Philippine law, in A Perez (ed) The Filipino 
family: A spectrum of views and issues, Quezon City: University of the Philippines

Office of Research Coordination, 12-26

Parrenas, R S, 2005, Children of global migration: Transnational families and gendered woes, Palo Alto, CA: Stanford University Press

Pauli, J, 2008,A house of one’s own: gender, migration, and residence in rural Mexico,

American Ethnologist, 35, 1, 171-87

Pingol, A, 2001, Remaking masculinities: Identity, power, and gender dynamics in families

with migrant wives and househusbands, Quezon City, Philippines: University of the

Philippines Centre for Women’s Studies

Salgado de Snyder,V N, 1993, Family life across the border: Mexican wives left behind,

Hispanic Journal of Behavioural Sciences, 15, 3, 391-401

Schneider, D, 1980, American kinship: A cultural account (2nd edn), Chicago, IL:

University of Chicago Press

Shih, K, Pyke, K, 2009, Power, resistance and emotional economies in women’s

relationships with mothers-in-law in Chinese immigrant families, Journal of Family

Issues, 31, 3, 333-57

Silverstein, J, 1990, The problem with in-laws, Journal of FamilyTherapy,14,4,399-412

Torres-Mejia, P, 2000, Peasants, merchants, and politicians in tobacco production:

Philippine social relations in a global economy, Quezon City: Ateneo de Manila University Press 
vanVleet, K, 2002,The intimacies of power: rethinking violence and affinity in the

Bolivian Andes, American Ethnologist, 29, 3, 567-601

Vera-Sanso, P, 1999, Dominant daughters-in-law and submissive mothers-in-law?

Cooperation and conflict in South India. Journal of the Royal Anthropological Institute,

5, 4, 577-93

Vlahoutsikou, C, 1997, Mothers-in-law and daughters-in-law: politicizing confrontations, Journal of Modern Greek Studies, 15, 2, 283-302

Wert, S, Salovey, P, 2004, A social comparison account of gossip, Review of General

Psychology, 8, 2, 122-37

Wilson, A, 2012, Of love potions and witch baskets: domesticity, mobility, and occult

rumours in Malawi, Western Folklore, 71, 2, 149-73

Wolf, M,1972,Women and the family in rural Taiwan, Stanford, CA: Stanford University

Press 